\title{
Kitap Değerlendirmesi: Eirik Hovden. Waqf in Zaydī Yemen: Legal Theory, Codification, and Local Practice (Leiden: Boston: Brill, 2019). ISBN: ISBN 978-90-04-37772-1
}

\section{Hatice Kübra Kahya* ${ }^{*}$}

İslam hukukunu salt normatif ve kat1-değişmez bir gerçeklik olarak gören geleneksel oryantalist söyleme karşı, Batı akademi çevresinde Wael B. Hallaq, Brinkley Messick, Baber Johansen ve Martha Mundy gibi isimlerce tarihi, sosyolojik ve antropolojik verilere dayalı alternatif bir söylem geliştirildi. Eirik Hovden'ın Waqf in Zaydī Yemen: Legal Theory, Codification, and Local Practice adlı çalışması ise her iki söylemin sentezinden üretilmiş disiplinlerarası bir söylem geliştirerek, bunu Yemen yerelinde uygular. F1khı farklı yerel formlara bürünebilen değişken bir kurum olarak inceleyerek, Yemen hayrî vakıflarının tarihi serüveni üzerine bir anlama çabası ortaya koyar.

Eserin giriş niteliğindeki birinci bölümünde coğrafi, tarihi ve sosyal yönleriyle Yemen'in kısa bir tanıtımı yapılarak, araştırmanın temel kaynakları ve yöntemi hakkında bilgi verilir. İkinci bölüm ise İslam hukukunda geçerliliği (validity) neyin temsil ettiği sorusuna ayrilır. Bu sorunun analizi noktasında, İslami ilimler, tarih ve antropolojinin teori, metot ve kaynakların bir araya getiren disiplinlerarası bir yöntem benimsenir. İslam hukuku çalışmalarında Batı akademik çevresine hakim olan norma odaklı metin merkezli yaklaşımla, nispeten daha yeni olan ve İslam hukukunu bir etnografik/antropolojik, sosyal ve hukuk tarihi çalışması olarak ele alan yaklaşım arasında yöntemsel bir sentez yapar ve Yemen örneği üzerinde "metin" ile "gelenek"e odaklanan bu iki yöntem arasında bir köprü kurar. Hovden, Fredrik Barth'ın "bilgi” teorisini kullanarak, vakıf kurumuna ilişkin bilginin geçerliliğini belirleyen dört katmanlı bir model geliştirir. Bilginin farklı cihetlerini ya da kaynaklarını sunan bu modelin katmanlarını, fikıh metinleri, yasalar, mahkeme kararları ve vakfa ilişkin gündelik bilgi oluşturur.

\footnotetext{
* Sorumlu Yazar: Hatice Kübra Kahya (Arş. Gör.), İstanbul Üniversitesi, Illahiyat Fakültesi, İslam Hukuku Ana Bilim Dalı, İstanbul, Türkiye. E-posta: hatice.kahya@istanbul.edu.tr ORCID: 0000-0002-1976-7354

Atrf: Kahya, Hatice Kubra. "Waqf in Zaydī Yemen: Legal Theory, Codification, and Local Practice." Eirik Hovden'ın Waqf in Zaydī Yemen: Legal Theory, Codification, and Local Practice adlı eserinin tanıtımı. darulfunun ilahiyat 31, 1 (2020): 197-199.

https://doi.org/10.26650/di.2020.31.1.0021
} 
Üçüncü bölümde Yemen vakıfları üzerine bugüne kadar yapılmış etnografik, tarihi ve hukuki çalışmalardan istifade edilerek, Yemen merkezi vakıf idaresinin 957/1550 yılında Osmanlı Devleti'nin burayı fethinden günümüze kadarki gelişimi ele alınır. Hovden, merkezi idarenin güçlendiği dönemlerde, vakıf kurumu üzerindeki merkezi kontrolün de arttı̆̆ını tespit eder. Ona göre bunun en belirgin örneği 19111948 yılları arasında hüküm süren İmam Yahya döneminde, kullanım dışı kalan münderis vakıfların, yeni kurulan Maarif Nezareti'nin reformlarının finansmanında kullanılmasıdır. Bunu mümkün kılmak adına çıkarılan iradelerle, vakıflar yeni bir hukuki sınıflamaya tabi tutulmuştur. Bu süreçte türbe vakıflarını geçersiz kılan çeşitli idari reformlar da gerçekleştirilmiş ve vakıfları merkezileştiren bu ve benzeri reformlar sonraki yıllarda da artarak devam etmiştir.

Dördüncü bölümde yazarın geliştirdiği dört katmanlı bilgi modelinde yer alan fikıh metinleri ve yasalar kategorisine giren Zeydî mezhebinin temel fikıh metinleri, fetva koleksiyonları, Zeydî imamların iradeleri ve hükümet kararlarının tanıtımı yapılır. Her biri özel başlık altında incelenen Zeydî fikıh metinleri arasında, İmam Yahya b. Hamza'nın (749/1348) el-İntisâr' ', meşhur Zeydî alim İbnü'l-Murtezâ'nın (840/1437) Kitâbü'l-ezhâr ve el-Bahru'z-zehhâr'1, İbn Miftâh'ın (877/1472) Şerhu'lezhâr'1, İmam el-Hâdî İzzeddin'in (900/1445) fetva koleksiyonu, Muhammed b. Ali eş-Şevkânî'nin el-Fethu'r-rabbânî, en-Neylü'l-evtâr ve es-Seyfü'l-cerrâr gibi önemli eserler yer alır. Yasa kategorisini ise Zeydî imamların ihtiyârât adı verilen doktrinel tercihe dayalı iradeleri ve fikhî metinlere referansı bulunmayan maslahat merkezli diğer fermanları ile hükümet kararları oluşturur. Sonraki üç bölümde ise geliştirilen dört katmanlı bilgi modelinin üç ayrı fıkıh problemi çerçevesinde pratiği sunulur.

Beşinci bölümde servetin nesiller arası intikalindeki belirleyici rolleri çerçevesinde, aile vakfı, miras ve vasiyet kurumları ele alınır. Hovden, miras hukuku kurallarının etrafını dolanmak için kullanılan aile vakfının, Zeydî imam ve alimlerin yaklaşık yarısı tarafından, meşru bir hukuk kurumu olarak görüldüğünü, ancak diğer yarısının kimi mirasçıları aile servetinden mahrum bırakan bu uygulamaya karşı çıktığını tespit eder. Ayrıca bu mezhebî ayrışmaya dayalı olarak evlâd-ı benâtın vakıf kurma veya vasiyet yoluyla mirastan mahrum bırakılmasının leh ve aleyhindeki değişken kanunların kronolojisini ve bu kanunların Zeydî fikıh geleneğinden nasıl beslendiklerini ortaya koyar. Mahkemeye taşınan aile vakıflarına ilişkin sosyal ve antropolojik bir inceleme yapan yazar, dışarıdan evli kız evladın alt nesillerinin, bu konudaki temel davacı grubu oluşturduğu tespitini yapar.

Altıncı bölüm vakıf gayrimenkullerin kiralanmasına ilişkin azami üç yıllık kısıt kuralının tarihsel gelişimini ve günümüz Yemen vakıf mevzuatına dahil oluş 
serüvenini inceler. Kitap ve sünnette yer almayan bu üç y1l kural1, diğer mezheplerde olduğu gibi Zeydî mezhebi doktrinine de sonradan dahil edilmiştir. Temel hedef uzun süreli kiralamalar neticesinde vakıf gayrimenkullerin, kiracısının özel mülkü gibi algılanmasına engel olmaktır. Bu kural, aynı zamanda, vakfın kira bedelinin piyasa fiyatı altında kalmasına engel olmak adına, vakıf mütevellisine belirli periyotlarla kira bedelinde revizyona gitme imkânı sunar. Üç yıl kuralını önemli kılan bir diğer husus, mezhebî meşruiyetin tespiti noktasında şerh-metin ilişkisinin önemini ortaya koymasıdır. Zira muhtasar türü Zeydî fikıh metinlerine dahil edilen bu kuralın sonraki şerh geleneğinde yerleşik pek çok istisnası vardır ve bu kural Zeydî gelenekte yer eden istisnalarıyla birlikte imâmî iradelere ve sonrasında da Yemen hükümet yasalarına dahil edilmiştir.

Yedinci bölümde vakıf kurucusu, varisleri, vakıf mütevellisi ve kiracıları gibi hayrî vakıflardaki özel hak sahiplerinin, vakfın, salt kamusal bir kurum olma hüviyetini nasıl ortadan kaldırdıkları tasvir edilir. Arı Hukuk, Örf ve Maslahat adını taşıyan sonuç bölümü ise Yemen uleması ve yerel halkı nezdinde "arı" İslam hukuku mefhumunun nasıl algılandığı ve kamu menfaati, eleştirel gerçeklik ve yasal geçerlilik gibi kavramların, vakfın, refahın potansiyel bir aracı olarak kullanımına nasıl tesir ettiğini ortaya koyar. Eser, ele aldığı bu problemler ve kullandığ kaynaklar itibariyle Zeydî mezhebi ve Yemen gibi hem doktrinel anlamda hem de bölge itibariyle ihmale uğramış bir alanı doldurarak, İslam hukuku literatürüne büyük bir katkı sağlamıştır. 
